\title{
The implementation of Land Consolidation in Planning of Urban Slum Area as Environmental Based Optimization of Urban Land Use and Utilization
}

\author{
Joko Suhendro ${ }^{1}$ I Gusti Ayu Ketut Rachmi Handayani ${ }^{2}$ Lego Karjoko ${ }^{3}$ \\ ${ }^{123}$ Universitas Sebelas Maret \\ Surakarta, Indonesia \\ Jokendro@gmail.com
}

\begin{abstract}
The 1945 Constitution specifically article $28 \mathrm{H}$ and Law No. 32 of 2009 regarding Environmental Protection and Management mandate that every citizen has the constitutional right to live physically and mentally prosperous, to live, and to have a good and healthy environment and to receive health assistance. The purpose of this research is to study further where the arrangement of urban slums through the land is positive for the optimization of urban land use and utilization. Land consolidation is carried out by arranging areas that were once slums to be organized, neat, habitable and environmentally friendly to support sustainable development and environment. The research method in this study is normative legal research that is research that has the object of research on the principles or rules of law. Normative legal research discusses the rules or regulations of a building system associated with a legal event. The facts show that land tenure in slums is disorganized and does not pay attention to living systems, one of them is the inadequate sanitation systems. The findings indicates that the land occupied by the community is Surakarta's governmentowned land that is not utilized and left empty at that time, which was later occupied by people who do not own any land.
\end{abstract}

Keywords- Planning, slums, land consolidation, environmental-based.

\section{INTRODUCTION}

Nowadays, environmental problems become increasingly important as a result of the declining function of the environment in sustaining human life. Issues relating to the pollution of the human environment have received strict attention from the community both nationally and internationally. Problems such as increasing population, poverty, high rates of urbanization, industrial development, use and utilization of space that is not under spatial planning, use and utilization of space that does not notice environmental sustainability, and many interests involved in the use and utilization of land are the causes the problem of environmental damage.

The use and utilization of land that is not suitable, especially in urban areas, is the leading cause of environmental damage. This can be seen in the use and utilization of land in urban areas that are disorganized (populous), weak sanitation systems, inadequate road access, lack of open space, lack of water absorption, poor waste and waste disposal systems, all of which cause environmental imbalances.

One of the problems in urban areas related to the environment is the existence of urban slums, which mostly occupy unused land, either government-owned land, private-owned land, or individual-owned land. Low income/poor communities occupy most of the slums. Poverty does not only occur in rural areas, but many also occur in urban areas, even poverty in urban areas is a problem that is difficult to overcome, especially those associated with urban slums that are mostly inhabited by low-income citizens (poor). Related to slum areas and poverty, this problem has a relatively complex range of issues relating to legal, social, economic, political, order and security, and environmental issues.

The more the development of human civilization, the more complex the problems of land, especially the problems of land use and utilization that occur in urban areas. The urban centre area is usually a destination for people to live and trade or do business in cities that incidentally does not increase in size, while the need for land is increasing. The many interests of various parties in the use of land in urban areas also add to the complexity of the problem of spatial planning in urban areas, and the higher land prices in urban areas contribute to the difficulty of owning land for the poor.

In dealing with the problems of poverty and slums that have not been resolved, it is necessary to optimize the arrangement, control, use and utilization of urban land through land consolidation so that it becomes a way out for the government to realize the social function of the land and the quality of the urban environment orderly and neat and environmentally friendly which in turn will create community welfare.

In line with the mandate of the 1945 Constitution Article 33 paragraph 3 which states "Earth, water and natural resources contained are controlled by the state and used as much as possible for the prosperity of the people." In the concept of land consolidation, the mandate stands as the basis for the right to control for the state, to regulate and synchronize the arrangement control, and use and utilization of land.

Related to the arrangement of urban slums through the concept of land consolidation as an effort to optimize the planning, control, use and utilization of urban land with environmental insight, this is related to Article $28 \mathrm{H}$ which regulates the rights of every citizen, as follows:

1. Everyone has the right to live in physical and spiritual prosperity, to live, and to have a great and healthy living environment and the right to health services. 
2. Every person has the right to get appropriate facilities and treatment to obtain equal opportunities and benefits in order to achieve equality and justice.

3. Every person has the right to social security that enables their full development as a dignified human being.

4. Everyone has the right to have private property rights, and these property rights may not be taken arbitrarily by anyone.

Referring to the Head of National Land Agency Regulation No. 4 of 1991 concerning land consolidation, land consolidation can be carried out in rural areas as well as in urban areas. In this case, the arrangement of urban slums is carried out with the concept of urban land consolidation, which is a policy relating to rearranging land both in terms of land tenure and land acquisition in the interest of development in order to improve the quality of the environment and preserve natural resources by involving citizens to play a role actively. The concept of land consolidation in the management of slums is one of the efforts to optimize the use and utilization of land with environmental insight and in line with the aims and objectives of Law number 32 of 2009 concerning environmental protection and management.

In connection with the preceding, the Government through the Ministry of Public Works and spatial planning implement a development program that is a program of a city without slums activities carried out in the Regency/City Government in Indonesia, including in the City of Surakarta. In connection with this, the Surakarta City Government through Surakarta Mayor Decree No. 413.21/38.3/1/2016 establishes a residential neighbourhood and slums in Surakarta, with an area of 359.5 hectares of slums, which are spread in various villages in the Surakarta. This slum will be structured so that the control over the use and utilization of the land becomes more optimal.

\section{RESEARCH METHODS}

This research used normative legal research as a method of research. Normative legal research is research that discusses the legal aspects, by conducting library research that is oriented to the laws and regulations that apply with the method of legislation approach, because it is legal research that is always normative. [1]

\section{FINDINGS AND DISCUSSION}

The main factor of the existence of urban slums begins from severe socio-economic conditions as a result of the development of an increasingly advanced city. The pattern of the arrangement, control, use and utilization of space in urban areas that are not take sides with the poor, the rapid flow of urbanization, urban development as a business/industrial centre, and expensive land prices that are not affordable for the poor are the factors that cause the emergence of urban slums. The problem of urban slums is experienced by almost all countries in the world, especially in cities that are busy as trade centres, including the City of Surakarta.

One of the provisions which become the legal basis for environmental management and natural resource utilization is Article 28 and Article 33. In the amendment to the 1945 Constitution, new provisions relating to environmental management and the use of natural resources, including Article $28 \mathrm{H}$ paragraph (1) and Article 33 paragraph (4) and (5) of the 1945 Constitution. Article $28 \mathrm{H}$ paragraph (1) states that "every person has the right to live in physical and spiritual prosperity, to live, and to have a good and healthy environment and to have health services." Article 33 Paragraph (4) of the 1945 Constitution "The national economy shall be implemented based on economic democracy with the principle of togetherness, fair efficiency, sustainability, environmental insight, independence, and by maintaining a balance of progress and national economic unity." In contrast, Article 33 paragraph (5) confirms that further provisions are regulated by law.

The 1945 Constitution states that a good and healthy environment is a human right and constitutional right for every Indonesian citizen. Therefore, the state, the government, and all stakeholders are obliged to carry out environmental protection and management in the implementation of sustainable development so that the Indonesian environment can remain a source and support of life for the people of Indonesia and other living things.

The government, with the approval of the House of Representatives, has several times declared laws concerning environmental management as follow:

1. Law Number 4 of 1982 regarding Basic Provisions for Environmental Management;

2. Law Number 23 of 1997 regarding Environmental Management;

3. Law Number 32 of 2009 regarding Environmental Protection and Management. [2]

Among the things that form the basis for the enactment of this Law are the national economic development which is carried out based on the principles of sustainable development and environmental insight. Philosophically, Law Number 32 of 2009 Regarding Protection and Management and Protection of Life, this views and respects that the importance of human rights in the form of the right to a good and healthy environment for citizens. [3]

The concept of urban land consolidation is very appropriate to be used as a means of overcoming the problems of urban slums. With the consolidation of this land, the arrangement, control, use and utilization of land that was previously disorganized has become organized, neat, livable, and fulfils environmental management requirements. Areas that were previously disorganized, with inadequate sanitation, lack access to roads, lack of open space became clean and livable areas as the fulfilment of human rights for every citizen to a good and healthy environment as referred to in Law 32 the year 2009.

\section{Urban Slums as a Result of Inequality of Population Income.}

The population living in cities is very diverse. Various kinds of professions and jobs are carried out by residents who live in urban areas. They work in the formal and informal sectors, in government and private sector, with very diverse income levels, ranging from deficient income 
levels to very high-income levels. This situation causes a high level of income inequality which is described on the Lorenz curve referred to as "gini ratio". The average gini ratio in Indonesia is still quite high at 0.380 in 2019 , while the urban gini ratio is higher at 0.391 while the rural gini ratio is lower at 0.262 , based on Central Statistics Agency data.

Gini Ratio is a tool to measure the degree of inequality in population distribution. This is based on the Lorenz curve, which is a cumulative expenditure curve that compares the distribution of a particular variable (for example income) with a uniform distribution that represents the cumulative percentage of the population. The Gini coefficient (Gini Ratio) is a measure of inequality or aggregate inequality (as a whole) whose numbers range from zero (perfect equalization) to one (perfect inequality).

This high number of gini ratio coefficient illustrates the broad level of income inequality that causes low-income people to be socio-economically marginalized. They are unable to have land for shelter because land prices are not affordable for them. Though they have to work to make a living in the city, this situation makes them forced to stay and occupy vacant land that is uninhabited just for themselves and their families to shelter and rest at night. In general, they live and occupy riverbanks, railroad tracks, grave edge land, and another vacant land. It was here that the slums began to emerge, those who lived and occupied the vacant lands built houses over time and eventually formed a residential area.

\section{The Concept of Land Consolidation by "Building without Displacing" From Slum Areas to Environmental Areas.}

The concept of planning urban slums through the "City without slums" program is the concept of building without evicting, how development continues to run well, affected people can continue to live and live even better is a noble goal of the program "Cities without slums". Data shows that the residents who occupy the land and become slums are all low-income residents with the majority of their livelihoods being day labourers or casual labourers who are not able to buy land in the city. All of the strategic issues mentioned above, of course, also have legal implications that must be addressed based on the provisions and applicable legal rules.

Based on the Regulation of the Head of the National Land Agency no. 4 of 1991 concerning land consolidation referred to as land consolidation under article 1 paragraph (1) is a land policy regarding the restructuring of land tenure and use and land acquisition efforts for development purposes, to improve environmental quality and preservation of natural resources by involving active participation Public. Article 2 paragraph (1) states that the purpose of implementing land consolidation is to achieve optimal land use, through increasing the efficiency and productivity of land use, paragraph (2) The goal of land consolidation is the realization of an orderly and orderly control and use of land. This goal is expected to be achieved in the arrangement of slums in Surakarta. The implementation of land consolidation concept in the arrangement of slums is expected to optimize the land use and utilization through the effectiveness and productivity of its function.

Article 3 Paragraph (1) in the context of improving environmental quality and at the same time providing land for the construction of public infrastructure and facilities, land tenure and stewardship arrangements are implemented in the form of land consolidation in urban and rural areas. Paragraph (2) land consolidation activities embrace the rearrangement of groups of land including land rights and/or land use, complete with road infrastructure, irrigation, environmental facilities and or other necessary supporting facilities, involving the participation of landowners and or land tenants.

In line with Article 3 of Law 32 of 2009, environmental protection and management aimed at:

a. Protect the territory of the Unitary Republic of Indonesia from environmental pollution and/or damage;

b. Ensure safety, health and human life;

c. Guarantee the survival of living things and the preservation of ecosystems;

d. Maintain environmental functions;

e. achieve harmony, compatibility, and environmental balance;

f. Ensure the fulfilment of the justice of present and future generations;

g. Ensure the fulfilment and protection of the right to the environment as part of human rights;

h. Control the rational use of natural resources;

i. Achieve sustainable development; and

j. Anticipate global environmental issues.

The arrangement of the land and spatial planning, control, use, and utilization is part of environmental management that is environmentally based. Constitutionally the environmental material about the environment has been stated in the opening and content of the 1945 Constitution. It is stated in the provisions of Article $28 \mathrm{H}$ paragraph (1), Article 33 paragraph (3), (4) and (5) of the 1945 Constitution.

According to General Explanation 1, Law Number 32 of 2009 Regarding Environmental Protection and Management, there are five crucial things in environmental management and natural resource utilization, among others:

a. Environmental management and utilization of natural resources must be placed within the framework of recognition, protection and fulfilment of the rights of every citizen of a good and healthy environment. In other words, human rights to a good and healthy environment cannot be sacrificed due to the implementation of development and utilization of natural resources;

b. Management of the environment and the use of natural resources is the responsibility of the State. The State makes rules and policies on the use of the environment and natural resources;

c. People's welfare becomes the philosophical and sociological basis for all activities and activities of 
environmental management and the utilization of natural resources used for people's welfare;

d. The management of the environment and the utilization of natural resources is a means to achieve sustainable development with an environmental perspective, in the sense that the targets of environmental management and the use of natural resources include not only the people's welfare but also aspects of environmental sustainability and national economic progress; and

e. There is a further delegation of regulations concerning environmental management by law. The 1945 Constitution states that a good and healthy environment is a human right and constitutional right for every Indonesian citizen. Therefore, the State, the government, and all stakeholders are obliged to carry out environmental protection and management in the implementation of sustainable development so that the Indonesian environment can remain a source and support of life for the people of Indonesia and other living things.

The enactment of Law Number 32 of 2009 concerning Environmental Protection and Management is a source of law in the context of the environment in Indonesia. Philosophically, Law Number 32 Year 2009 Regarding Protection and Management and Protection of Life, this views and respects that the importance of human rights in the form of the right to a good and healthy environment for citizens. [4]

Law No. 32 of 2009 emphasizes more on regulatory principles aimed at providing guarantees for the realization of sustainable development and ensuring the environment can be protected from businesses or activities that cause environmental damage or pollution.

From the above explanation, it seems clear that there is a link between the norms of "sustainable development" and "environmentally sound". All strategies and policies relating to the environment require specific constitutional interpretations when state actors want to carry out economic activities. This must be understood solely to prevent a more significant negative impact on the destruction of nature and the environment. [5]

Environmental law itself is a field of law that has a peculiarity which Drupsteen calls the functional law field (functioneel rechtsgebeid), in which there are elements of administrative law, criminal law and civil law. Therefore, environmental law enforcement can be interpreted as the use or application of instruments and sanctions in the field of administrative law, criminal law, and civil law to force the subject of the law subject to compliance with environmental legislation. [6] The use of civil legal instruments, namely civil lawsuits, can be carried out by citizens, public legal entities and also government agencies. However, when compared between legal fields, most of the norms of environmental law fall under the jurisdiction of administrative law. Agrarian resources, especially land, are national wealth that can bring enormous benefits. On the other hand, it is also a cause of many serious problems such as land disputes and conflicts. The source of agrarian conflict lies in the presence of many inequalities and incompatibilities. In Indonesia, there are at least two kinds of inequality, those are:

a) Inequality of land tenure and ownership;

b) Inequality in the case of the use of land utilization;

c) Incompatibilities in terms of perceptions and conceptions about agrarian. [7]

Because of income inequality, these disparities are the forerunner to poverty and have an impact on the emergence of slums. Economic development which tends to lead to industrialization as a means of entering the era of globalization in creating investment opportunities requires land on a large scale. With a substantial capital strength and support from several laws and regulations, the owners of capital are free in control of the vast productive land. This has become one of the drivers of inequality in land ownership between the community and the capital owners.

Inequality of ownership of land is caused by the difficulty of finding land and the unreachable price of land, which is the cause of the appearance of slums, especially in urban areas. The emergence of urban slums is a central problem and is experienced by almost all cities in the world, and there must be a serious effort to overcome this situation through the implementation of development programs, especially environmentally sustainable development. In Indonesia, the Gini ratio for land tenure and ownership is still quite high, that is above 0.5.

The study of sustainable and environmentally based development, the Government through the Ministry of Public Works and Public Housing has a development program that is urban slum structuring through the "City without Slums" program, a development program for people living in slums to be developed into habitable areas, orderly, clean and meet the standards of excellent and healthy environmental management and legal certainty. One of the locations of the implementation of the "City without Slums" program is in the City of Surakarta, which is the "most urban" area compared to the surrounding regions. So that many slum problems are found compared to other areas in the vicinity.

The "City without slums" program itself is one of several strategic efforts by the Ministry of Public Works and Public Housing through the Regional Government to accelerate the handling of slums in Indonesia and support the "100-0-100 Movement" which is 100 per cent universal access to drinking water, 0 per cent slums, and 100 per cent access to proper sanitation. The "City without slums" program will build or deal with slums by building collaborative platforms through increasing the role of local government and community participation. The 100-0-100 movement is very much in line with efforts to realize the use and utilization of land with environmental insight. In the implementation of the city without slums program, the synergy between the Government and the community is crucial. Thus, the active role and participation of the people are essential for the success of the program.

Another consideration of the needs for community participation in governance are:

1. Community involvement is an essential element in developing and developing aspirational and democratic 
governance systems, capable of serving the interests and needs of the community well;

2. Participation as one of the principles of good governance needs to be developed in order to encourage citizens to use their thoughts and opinions in every decision making concerning their interests, implementation and evaluation of governance and development programs in their regions;

3. Community involvement, both directly and indirectly, will build partnerships between the government and the community to be jointly responsible for the success of government and development. [8]

Correlated with its provisions in Law Number 32 of 2009 concerning Environmental Protection and Management Article 70 Paragraph (1) states that "Communities have equal and broadest rights and opportunities to play an active role in environmental protection and management".

Indonesia is a state of law, a country categorized as a state of law if the state has given awards and guarantees of protection of human rights. Thus, as a state of law, the Indonesian state recognizes and protects the human rights of all individuals. Individual rights recognition from the state is implied on the principle of equality before the law for all people. Equality before the law, of course, must also be balanced with the existence of equal treatment. [9]

The presence of the urban slum structuring program through the "City without Slums" program can be a means of access to the right to a good and healthy environment through access to habitable and environmentally sound areas and also the legal certainty of ownership of the land as part of constitutional rights as a form of equality in advance of law (equality before the law) against the poor.

Van Apeldoorn mentions that "rights" have the meaning of something that is regulated by law which is based on power, but that power is not a right. The only power is justified by law as a basis for justifying the right to rule by the state. The term "rights" is the subject of debate, both in the legal context and in the political context, some people mention it "natural" or "basic", but it is a "claim" or demand. [10]

\section{CONCLUSION}

Based on the description above, conclusions can be drawn as follows taking the arrangement of slum areas with the concept of land approval becomes an alternative to create a healthy and environmentally friendly settlement area for low-income people as a place for human negotiations by negotiating the government's commitment for fulfilling the constitutional rights of its citizens, mandate number 32 of 2009. Handling the arrangement of slums through optimal use of land and irrigation. As a suggestion, it can be conveyed as norms, standards, procedures and suggestions for the arrangement of slum areas through the "city without slums" program with the concept of land approval in the city of Surakarta.

\section{REFERENCES}

[1] M. Roestamy, "Model Land Supply for Land Bank to House Application Martin," Bestuur, vol. 7, no. 2, 2019.

[2] A. Jumari, "Potensi Pelanggaran Pengelolaan Limbah Bahan Berbahaya dan Beracun," J. Best., vol. 7, no. 2, 2019.

[3] Yusriando, "Konstruksi Sistem Jaminan Sosial Nasional Bidang Kesehatan Yusriando," Bestuur, vol. 7, no. 2, 2019.

[4] U. K. Mishra and A. Negi, "Transgender and the Right to Employment in India: Analysing the Trajectories of Discrimination," Bestuur, vol. 9, no. 1, pp. 34-43, 2021.

[5] L. C. Lintang, Adriano Martufi, and J.W. Ouwerker, "The Alternative Concepts of Blasphemy Law in Indonesia: Legal Comparison with Ireland and Canada," Bestuur, vol. 8, no. 2, pp. 121-128, 2020.

[6] S. R. Novikasari, D. Q. Ly, and K. Gershaneck, “Taxing Micro, Small and Medium Enterprises in Yogyakarta: Regulation and Compliance," Bestuur, vol. 9, no. 1, 2021.

[7] M. A. Mohd Sani and D. D. Abdul Hamed Shah, "Freedom of Religious Expression in Malaysia," J. Int. Stud., pp. 33-50, 2020.

[8] S. A. Estikomah, "Aspek Hukum Import Sampah Plastik," Bestuur, vol. 7, no. 2, p. 41, 2019.

[9] A. A. Hamzana, "Pelaksanaan Standarisasi Pelayanan Pariwisata Halal dalam Pengembangan Pariwisata di Nusa Tenggara Barat," Pena Justisia Media Komun. dan Kaji. Huk., vol. 17, no. 2, pp. 1-16, 2018.

[10] B. Prasetyo, I. G. A. K. R. Handayani, A. Sulistyono, and L. Karjoko, "Legal framework for social security state civil apparatus," Int. J. Adv. Sci. Technol., vol. 28, no. 20, pp. 310-313, 2019.

[11] I. Gusti Ayu Ketut Rachmi Handayani, G. Gunarto, A. Mashdurohatun, I. Gusti Putu Diva Awatara, and F. U. Najicha, "Politic of legislation in Indonesia about forestry and the mining activity permit in the forest area of environmental justice," Journal of Engineering and Applied Sciences, vol. 13, no. 6. pp. 1430-1435, 2018.

[12] A. K. Jaelani, I. G. A. K. R. Handayani, and L. Karjoko, "Development of tourism based on geographic indication towards to welfare state," Int. J. Adv. Sci. Technol., vol. 29, no. 3 Special Issue, pp. 1227-1234, 2020.

[13] R. D. Luthviati, "The Role of Local Governments in the Defense of Leading Products Resti," J. Best., vol. 8, no. 2, pp. 121-128, 2020.

[14] Yuliandri, G. A. K. R. Handayani, T. Prasetyo, K. Seregig, and H. Tegnan, "Retributive justice theory and the application of the principle of sentencing proportionality in Indonesia," J. Leg. Ethical Regul. Issues, vol. 21, no. 4, pp. 1-8, 2018.

[15] I. G. A. K. R. Handayani, H. Glaser, S. Monteiro, E. D. Kusumawati, A. K. Jaelani, and F. U. Najicha, "Water availability in the framework of environmental justice: reconstruction of municipal 
waterworks (pdam) regulations," Int. J. Business, Econ. Law, Vol. 20, Issue 4 2019, vol. 20, no. 4, pp. 51-55, 2019.

[16] I. Iswantoro, "Strategy and Management of Dispute Resolution, Land Conflicts at the Land Office of Sleman Regency," J. Hum. Rights, Cult. Leg. Syst., vol. 1, no. 1, pp. 1-17, 2021.

[17] A. Ma, "Legal Aspects of Environment in Indonesia : an Efforts to Prevent Environmental Damage and Pollution," J. Hum. Rights, Cult. Leg. Syst., vol. 1, no. 1, pp. 18-30, 2021.

[18] A. K. Jaelani and R. D. Luthviati, "The Crime Of Damage After the Constitutional Court's Decision Number 76 / PUU-XV / 2017," J. Hum. Rights, Cult. Leg. Syst., vol. 1, no. 1, pp. 31-41, 2021.

[19] R. Res, "Implementation of Parate Executie Object of Liability Juridical Overview of Mortgage," J. Hum. Rights, Cult. Leg. Syst., vol. 1, no. 1, pp. 42-53, 2021.

[20] Syahlan, "Effective and Efficient Synchronization in Harmonization of Regulations Indonesia," J. Hum. Rights, Cult. Leg. Syst., vol. 1, no. 1, pp. 54-70, 2021.

[21] R. I. Ichlas, "Questioning the Independence of Media Coverage in the 2019 Elections," J. Best., vol. 8, no. $1,2020$.

[22] W. N. Hanum, "Setting of Earth Oil Management in Old Wells Based on the Principle Social Justice," Bestuur, vol. 8, no. 2, p. 70, 2020.

[23] K. Intaniasari, "Gross Split Contract Framework Regulation on the Caring for People," Bestuur, vol. 8, no. 2, p. 96, 2020. 